\title{
Population genetic structure of Sedum polytrichoides (Crassulaceae): Insights into barriers to gene flow
}

\author{
Mi Yoon Chung, Jordi López-Pujol ${ }^{1}$ and Myong Gi Chung* \\ Division of Life Science and the Research Institute of Natural Science, Gyeongsang National University, Jinju 52828, Korea \\ ${ }^{1}$ BioC-GReB, Botanic Institute of Barcelona (IBB-CSIC-ICUB), Passeig del Migdia s/ $n$, Barcelona 08038, Spain
}

(Received 24 November 2016; Revised 2 December 2016; Accepted 13 December 2016)

\author{
바위채송화(돌나물과)집단의 유전적 구조: \\ 유전자 이동과 물리적 장벽에 관한 통찰 \\ 정미윤 · Jordi López-Pujol · 정명기* \\ 경상대학교 생물학과 및 기초과학연구소, ${ }^{1} \mathrm{BioC}-\mathrm{GReB}$, 바르셀로나식물원연구소, 스페인
}

\begin{abstract}
An area comprising Juwangsan National Park and its adjacent mountains (southeastern Korean Peninsula) is a good model system for testing the effects of physical barriers to gene flows in plant populations. We predicted that plant species consisting of isolated populations are genetically more differentiated than those that are rather continuously distributed. Most populations of Sedum polytrichoides occur in four isolated valleys, and we assessed the genetic variability and structures using twelve allozyme loci in ten populations. We also compared the present results to earlier findings pertaining to the two co-occurring herbs Hylotelephium ussuriense ( $\equiv$ Sedum ussuriense) (growing only in the four isolated valleys) and $S$. kamtschaticum (rather continuously distributed). We found moderate levels of within-population genetic variation in $S$. polytrichoides $\left(H_{\mathrm{e}}=0.112\right)$. Estimates of among-population divergence in $S$. polytrichoides were also moderate $\left(F_{\mathrm{ST}}=0.250\right)$ and, as expected, very similar to that of $H$. ussuriense ( 0.261$)$ but considerably higher than the variation in $S$. kamtschaticum (0.165). An analysis of molecular variance (AMOVA) revealed that S. polytrichoides and H. ussuriense had higher percentages of among-valley variation (19\% each) than S. kamtschaticum $(4 \%)$. Most of this variation, as also indicated by the STRUCTURE program, was due to differences in genetic profiles between the two central valleys. We concluded that the genetic differences observed between species (S. kamtschaticum vs. S. polytrichoides and H. ussuriense) are mainly due to differences in their distribution within the study area.
\end{abstract}

Keywords: gene flow, genetic differentiation, genetic diversity, physical barrier, Sedum

적 요: 한반도 남동부에 위치한 주왕산 국립공원과 그 인접산지는 식물 개체군의 유전자 이동에 대한 물리 적 장벽의 영향을 시험하기 위한 훌륭한 모델 시스템이다. 우리는 식물종의 경우, 격리된 집단이 연속적인 분포를 보이는 집단보다 유전적인 분화 정도가 더 클 것으로 예측했다. 바위채송화 대부분의 집단은 4곳의 고립된 계곡에서 생육하며, 10 개 집단에서 12 종류의 알로자임 유전좌위를 사용하여 유전적 다양성과 구조 를 평가했다. 저자들은 이 연구와 기존 연구된 둥근잎꿩의비름(4곳 계곡에서 격리되어 생육)과 기린초(상대 적으로 연속적으로 분포) 결과와 비교했다. 우리는 기린초 집단내 유전적 변이가 중간 수준임을 발견했다 $\left(H_{\mathrm{e}}=0.112\right)$. 바위채송화 집단간 분기 수준도 중간 수준 $\left(F_{\mathrm{ST}}=0.250\right)$ 이었고 예상대로 둥근잎뀡의비름 $(0.261)$ 과

\footnotetext{
*Author for correspondence: mgchung@gnu.ac.kr
} 
유사했지만 기린초(0.165)보다 상당히 높았다. 분자분산분석(AMOVA) 결과 바위채송화와 둥근잎뀡의비름은 기린초(4\%)보다 계곡간 변이(각각 $19 \%$ ) 비율이 높았다. STRUCTURE 프로그램 분석에 의하면 대부분의 이런 변이는 중간에 있는 두 계곡간의 유전적 조성 차이 때문이다. 저자들은 종간에 관찰된 분화 수준의 차이(즉, 기 린초 대 바위채송화와 둥근잎꿩의비름)는 연구 지역 내의 그들의 분포 차이에 기인한다고 결론지었다.

주요어: 유전자 이동, 유전적 분화, 유전적 다양도, 물리적 장벽, 돌나물속

It is generally known that geographic isolation is one of the main factors shaping the genetic structure of plant populations (Smith, 1999; Hamilton and Eckert, 2007; Yamada and Maki, 2012). Physical isolation of populations, either natural (e.g., mountains, valleys, rivers, lakes, and glaciers) or human-caused (e.g., highways, channels, and walls) are discontinuities of suitable habitat that may restrict or prevent gene flow, eventually leading to strong genetic differentiation between isolated populations (Slatkin, 1987; Le Corre et al., 1997; Su et al., 2003; Zhang et al., 2007; Landguth et al., 2010). As shown in some empirical studies, such differentiation can be attained just after a few generations, sometimes with no need of huge physical barriers; a classical example is the Great Wall of China, whose barrier effects are genetically detectable after just six centuries ( $\mathrm{Su}$ et al., 2003). In South Korea, the construction of roads, coupled with the establishment of new villages and the expansion of paddy fields have led to significant increases in genetic differentiation in island populations of the terrestrial orchid Cymbidium goeringii in less than two centuries (Chung et al., 2014c).

Juwangsan National Park (JNP), one of the 22 national parks of South Korea, is located in a mountainous branch of the Baekdudaegan (the so-called Nakdongjeongmaek Range), in the southeastern corner of the Peninsula (Fig. 1). The park, as well as some surrounding areas, are largely made of volcanic ash tuffs ca. 70 Ma old, with many vertical cliffs in canyons and deep valleys originated by erosion of volcanic rocks (Hwang et al., 2007) that deeply dissect the landscape. Thus, this region constitutes a natural laboratory to test the effects of barriers on population divergence. We have selected an area of ca. $250 \mathrm{~km}^{2}$ that contains four valleys separated by mountain ranges; two valleys, Juwang and Jeolgol, are located within JNP, whereas Okgye and Haok valleys are in its vicinity (Fig. 1). As one may expect, in this region some plant species are restricted to valleys whereas others are distributed rather continuously (ca. $15 \mathrm{~km}$ range) (Fig. 1). For example, Hylotelephium ussuriense (Kom.) H. Ohba ( $\equiv$ Sedum ussuriense Kom.) is found only in the four valleys but does not occur in the mountains in between ( $\mathrm{Ku}$ et al., 2011). In contrast, Sedum kamtschaticum Fisch. \& C. A. Mey. co-occurs in the four valleys but also on the intervening mountains in
JNP and its vicinity. To understand better the effects of physical isolation on the genetic structure of plant populations in the study area, recently we comparatively assessed genetic variability and structure in 12 population pairs (three sympatric populations per valley for each species) of the two stonecrops (Chung et al., 2014b). The authors found high and comparable levels of within-population genetic variation for the two species, although among-population difference was significantly higher in $H$. ussuriense than in $S$. kamtschaticum $\left(F_{\mathrm{ST}}=0.261\right.$ vs. $F_{\mathrm{ST}}$ $=0.165)$. In addition, the former exhibited a much higher percentage of among-valley variation (19\%) than the latter (4\%).

As plant congeners usually share similar life-history traits, in particular breeding systems and seed dispersal mechanisms, comparisons of congeneric species pairs allow for partial control of "background variation" (or "phylogenetic inertia")

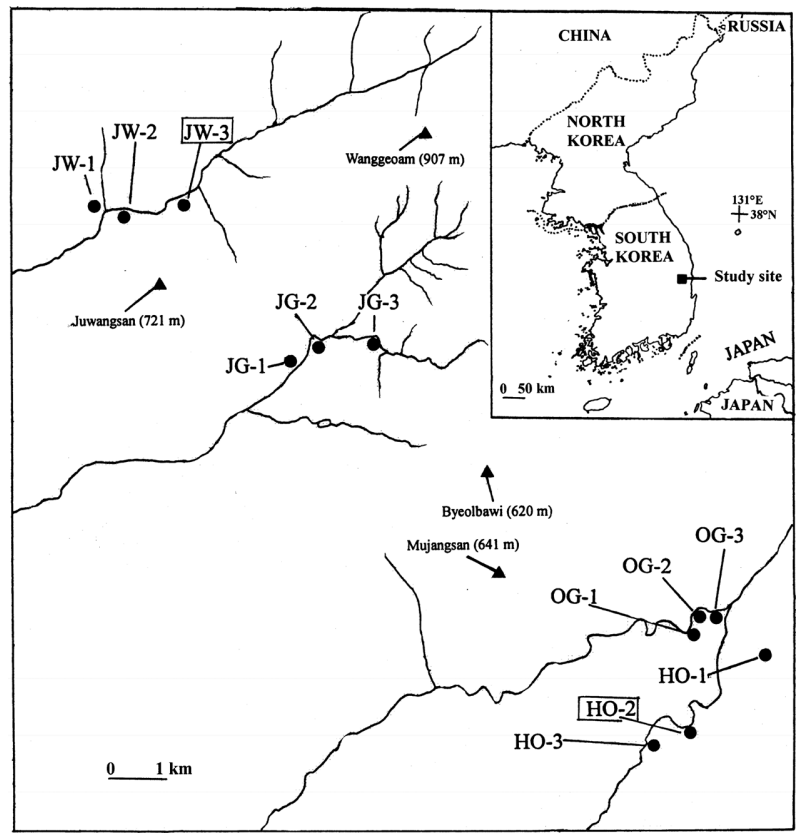

Fig. 1. Locations of sampled populations of Sedum polytrichoides from Juwangsan National Park (JNP, areas comprising Juwang and Jeolgol valleys) and its vicinity. Solid lines indicate streams that run through valleys: JW, Juwang Valley; JG, Jeolgol Valley; OG, Okgye Valley; HO, Haok Valley. In the inset, the study site is indicated. Note that $S$. polytrichoides does not occur at the two populations enclosed by boxes (JW-3 and HO-2), but $S$. kamtschaticum and Hylotelephium ussuriense grow there (Chung et al., 2014b). 
caused by different life-history traits (Karron, 1987, 1991, reviewed in Godt and Hamrick, 2001). With this in mind, we selected Sedum polytrichoides Hemsl., an additional stonecrop that is also present in the study area, to get additional insights into the previous results by Chung et al. (2014b). The species is somewhat common along the four valleys, but several populations also occur on rocks in mountains and hillsides between valleys. The three species are insect-pollinated $(\mathrm{Ku}$ et al., 2011; Chung et al., 2014b; M. Y. Chung, pers. obs.), and we assumed that their seed dispersal mechanisms would be similar.

Given the current occurrence patterns of the three stonecrops, the high habitat specificity, and the isolated nature of the valleys, we expect an increase of genetic differentiation in the following order: $H$. ussuriense, $S$. polytrichoides, and $S$. kamtschaticum. In particular, we expect that the pattern and degree of among-population differentiation of $S$. polytrichoides will be more similar to those found in $H$. ussuriense rather than S. kamtschaticum. To test these predictions, we used allozymes as genetic markers to estimate levels and structure of genetic diversity in JNP and its vicinity. If our predictions are supported, this study also would be a reference for emphasizing the importance of physical barriers for generating among-population genetic structure even at very small scales.

\section{Materials and Methods}

\section{Study species}

Sedum polytrichoides has $5-10 \mathrm{~cm}$ high stems, and inflorescences contain many small bright yellow flowers, visited by unidentified insects (M. Y. Chung and M. G. Chung, pers. obs.). Members of Sedum are known to be pollinated by a variety of insects, such as bees, flies, and butterflies, and both outcrossing and mixed mating have been reported (Wyatt, 1983; Priya, 2007). It usually grows in small crevices on rocks in medium-elevation mountains (ca. $1,000 \mathrm{~m}$ a.s.l.) in northeastern and eastern China, Japan, and Korea (Ohwi, 1965; Fu and Ohba, 2001). As a member of the temperate vegetation in Korea, it occurs relatively sparsely in mid-elevation mountains across the Peninsula. Within the study area, as stated above, $S$. polytrichoides is mainly restricted to the four valleys rocky cliffs, although a few populations occur in between.

$S$. kamtschaticum has 5-30 cm high stems with bright yellow flowers $(5-6 \mathrm{~mm}$ in diameter) that also attract insects. The species is widely distributed in Far East Asia, spanning Kamchatka, Ussuri, Kuriles, Sakhalin, the Japanese Archipelago, northern China, and the Korean Peninsula (Ohwi, 1965). On the Korean Peninsula, S. kamtschaticum is relatively common on rocks in mountains and hillsides; within the study area, it is a common plan, and rather continuously distributed.

H. ussuriense has $10-25 \mathrm{~cm}$ high stems, that carry many small magenta pink flowers $(5-6 \mathrm{~mm}$ in diameter) that are visited by insects (Ku et al., 2011). The species is disjunctly distributed in two areas: in JNP and its vicinity (but only in the small crevices of steep cliffs along the four valleys) and along the Tumen River (i.e., in the boundary between China, North Korea, and Russia) and the basin of the Ussuri River in Russia, over $700 \mathrm{~km}$ north (Ku et al., 2011).

\section{Population sampling}

We collected samples from 10 populations of $S$. polytrichoides $(\mathrm{n}=243$ samples) (Table 1$)$ at the same sites studied by Chung et al. (2014b) with the exception of two populations (JW-3 and HO-2) in JNP and its vicinity (Fig. 1). We chose one sample from tufted stems to prevent sample duplicates. To minimize the damage to these plants, we cut just $2 \mathrm{~cm}$ from the tip of one shoot.

\section{Enzyme electrophoresis}

We extracted enzymes using a phosphate-polyvinylpyrrolidone buffer (Mitton et al., 1979) and conducted electrophoresis on $13 \%$ starch gels. We resolved eight enzyme systems with two buffer systems. With a modification (Haufler, 1985) of the system 6 of Soltis et al. (1983), we resolved diaphorase (Dia-1, Dia-2), fluorescent esterase $(\mathrm{Fe})$, leucine aminopeptidase (Lap-1, Lap-2), malic enzyme (Me), phosphoglucomutase (Pgm-1, Pgm-2), and triosephosphate isomerase (Tpi-1, Tpi-2). Using the morpholine-citrate buffer system (pH 6.1) of Clayton and Tretiak (1972), we further resolved isocitrate dehydrogenase (Idh) and 6phosphogluconate dehydrogenase (6Pgd). We followed stain recipes from Soltis et al. (1983) except for diaphorase (Cheliak and Pitel, 1984). We designated putative loci sequentially, with the most anodally migrating isozyme designated as 1 , the next 2 , and so on. We also designated different alleles within each locus sequentially by alphabetical order $(a, b, c, d)$.

\section{Data analysis}

We considered a locus to be polymorphic when two or more alleles were observed, regardless of their frequencies. We estimated the genetic diversity parameters within populations using the programs POPGENE (Yeh et al., 1999) and FSTAT (Goudet, 1995): percentage of polymorphic loci $(\% P)$, mean number of alleles per locus $(A)$, allelic richness $(A R)$ corrected by minimum sample size $(\mathrm{n}=11$ in JGP-1) (Table 1), observed heterozygosity $\left(H_{\mathrm{o}}\right)$, and Hardy-Weinberg $(\mathrm{H}-\mathrm{W})$ expected 
Table 1. Levels of genetic diversity in 10 populations of Sedum polytrichoides from Juwangsan National Park and its vicinity.

\begin{tabular}{|c|c|c|c|c|c|c|c|}
\hline Taxon/population & $n$ & $\% P$ & $A R$ & $A$ & $H_{\mathrm{o}}(\mathrm{SE})$ & $H_{\mathrm{e}}(\mathrm{SE})$ & $F_{\text {IS }}$ \\
\hline \multicolumn{8}{|l|}{ S. polytrichoides } \\
\hline JWP-1 & 12 & 41.7 & 1.41 & 1.42 & $0.076(0.033)$ & $0.102(0.043)$ & $0.248^{\mathrm{a}}$ \\
\hline JWP-2 & 13 & 25.0 & 1.25 & 1.25 & $0.071(0.037)$ & $0.096(0.051)$ & $0.263^{\mathrm{a}}$ \\
\hline JGP-1 & 28 & 50.0 & 1.53 & 1.58 & $0.113(0.043)$ & $0.191(0.069)$ & $0.409^{\mathrm{a}}$ \\
\hline JGP-2 & 11 & 33.3 & 1.42 & 1.42 & $0.091(0.054)$ & $0.114(0.061)$ & $0.200^{\mathrm{a}}$ \\
\hline JGP-3 & 12 & 41.7 & 1.41 & 1.42 & $0.083(0.034)$ & $0.124(0.054)$ & $0.330^{\mathrm{a}}$ \\
\hline OGP-1 & 50 & 50.0 & 1.48 & 1.58 & $0.063(0.025)$ & $0.085(0.029)$ & $0.252^{\mathrm{a}}$ \\
\hline OGP-2 & 22 & 41.7 & 1.59 & 1.67 & $0.136(0.065)$ & $0.134(0.057)$ & -0.017 \\
\hline OGP-3 & 20 & 25.0 & 1.21 & 1.25 & $0.042(0.029)$ & $0.071(0.045)$ & $0.414^{\mathrm{a}}$ \\
\hline HOP-1 & 45 & 41.7 & 1.45 & 1.50 & $0.065(0.026)$ & $0.122(0.056)$ & $0.469^{\mathrm{a}}$ \\
\hline HOP-3 & 30 & 25.0 & 1.25 & 1.25 & $0.042(0.022)$ & $0.081(0.044)$ & $0.488^{\mathrm{a}}$ \\
\hline Average & 24 & 37.5 & 1.40 & 1.43 & $0.078(0.009)$ & $0.112(0.011)$ & $0.331^{b, c}$ \\
\hline Pooled samples & 243 & 75.0 & & 2.25 & & $0.144(0.045)$ & \\
\hline \multicolumn{8}{|l|}{ S. kamtschaticum } \\
\hline Average & 30 & 50.0 & 1.61 & 1.65 & $0.126(0.010)$ & $0.173(0.014)$ & $0.272^{\mathrm{b}, \mathrm{c}}$ \\
\hline Pooled samples & 360 & 66.7 & & 2.08 & & $0.203(0.062)$ & \\
\hline \multicolumn{8}{|c|}{ Hylotelephium ussuriense } \\
\hline Average & 34 & 56.3 & 1.50 & 1.64 & $0.122(0.006)$ & $0.156(0.007)$ & $0.246^{\mathrm{b}, \mathrm{c}}$ \\
\hline Pooled samples & 405 & 83.3 & & 2.42 & & $0.201(0.053)$ & \\
\hline
\end{tabular}

Genetic estimates from S. kamtschaticum and Hylotelephium ussuriense were from Chung et al. (2014b).

$\mathrm{n}$, the number of individuals; $\% P$, percentage of polymorphic loci; $A R$, mean allelic richness (adjusted for a sample size of 11 ); $A$, mean number of alleles per locus; $H_{\mathrm{o}}$, observed heterozygosity; $H_{\mathrm{e}}, \mathrm{H}-\mathrm{W}$ expected heterozygosity or genetic diversity; SE, standard error in parentheses; $F_{\text {IS }}$, fixation index within populations.

${ }^{\text {a }}$ Significant (at the 0.05 level) estimate of $F_{\text {IS }}$ within populations based on permutation (999 replicates) under the null hypothesis of $F_{\text {IS }}=0$.

${ }^{\mathrm{b}}$ Weir and Cockerham (1984) estimate of $F_{\text {IS }}$ over populations. ${ }^{\mathrm{c}}$ Significant (at the 0.05 level) Weir and Cockerham (1984) estimate of $F_{\text {IS }}$ over populations.

heterozygosity or Nei's (1978) gene diversity $\left(H_{\mathrm{e}}\right)$. Except for $A R$ and $H_{\mathrm{o}}$, these parameters were also estimated for the total samples as a whole (i.e., the species level).

To test for recent decreases in effective population size (bottlenecks), we evaluated differences across loci between the $\mathrm{H}-\mathrm{W} H_{\mathrm{e}}$ and the equilibrium heterozygosity $\left(H_{\mathrm{eq}}\right)$ expected assuming mutation-drift equilibrium. H-W $H_{\mathrm{e}}$ is not very sensitive to the fate of low frequency alleles, whereas $H_{\mathrm{eq}}$ is relatively sensitive to population bottlenecks, and declines as a result of the loss of such alleles. These differences $\left(H_{\mathrm{e}}-H_{\mathrm{eq}}\right.$ calculated for a number of independent loci) were evaluated using a sign test and a Wilcoxon sign-rank test under an infinite allele model using the program BOTTLENECK (Piry et al., 1999). Since allelic diversity is generally lost more rapidly than $H_{\mathrm{e}}$ (Nei et al., 1975), recently bottlenecked populations will exhibit an excess of $\mathrm{H}-\mathrm{W} H_{\mathrm{e}}$ relative to $H_{\mathrm{eq}}$ (Cornuet and Luikart, 1996).
We used the program SPAGeDi (Hardy and Vekemans, 2002) to calculate population-level $F_{\text {IS }}$ (inbreeding) and its significance level by 999 permutations under the null hypothesis of $F_{\mathrm{IS}}=0$. To measure deviations from $\mathrm{H}-\mathrm{W}$ equilibrium at each polymorphic locus, we calculated averages of Wright's (1965) $F_{\text {IS }}$ and $F_{\text {ST }}$ (deviations from $\mathrm{H}-\mathrm{W}$ equilibrium of individuals relative to their local populations and local populations relative to the total population, respectively) following Weir and Cockerham (1984). We determined the significance of multi-population $F_{\text {IS }}$ and $F_{\text {ST }}$ estimates by a permutation test ( 999 randomizations of alleles among individuals within samples and 999 randomizations of genotypes among populations, respectively). These calculations were also performed using FSTAT (Goudet, 1995).

To test for the influence of individuals within populations, populations within and among valleys, and populations within each region (considering Juwang and Jeolgol valleys as the 
"northern region," and Okgye and Haok valleys as the "southern region"; Fig. 1) on the observed genetic variation, we conducted an analysis of molecular variance (AMOVA) for each species using the program GenAlEx 6.5 (Peakall and Smouse, 2006).

Genetic structure among populations was assessed by means of the Bayesian algorithm implemented in STRUCTURE 2.3.4 (Pritchard et al., 2010). The program estimates the likelihood of the individuals being structured in a given number of genetic clusters (or genetic populations, $K$ ). The admixture ancestry model with correlated allele frequencies was selected as the most appropriate option for the analysis. The burn-in period and Markov Chain Monte Carlo (MCMC) were set to 50,000 and 500,000 iterations, respectively, and 10 replicates per $K$ were run. The most likely value of $K$ was determined both choosing the smallest $K$ after the log probability of $\operatorname{Pr}(X \mid K)$ values reached a plateau (Pritchard et al., 2010) and by the $\Delta K$ statistic of Evanno et al. (2005), with the aid of STRUCTURE HARVESTER (Earl and vonHoldt, 2012).

To test the overall pattern of genetic structure at the regional scale (i.e., isolation-by-distance effects), we conducted a Mantel test (Mantel, 1967) with 999 replicates, between all pairwise $F_{\mathrm{ST}} /\left(1-F_{\mathrm{ST}}\right)\left(F_{\mathrm{ST}}\right.$ was calculated following Weir and Cockerham, 1984) and the corresponding logarithm of pairwise geographic distances (Rousset, 1997) under the null hypothesis of no spatial genetic structure (regression slope, $\beta=0$ ).

\section{Results}

\section{Genetic diversity}

Nine of the 12 putative loci surveyed for S. polytrichoides were polymorphic (Table 2). As a result, moderate levels of average within-population genetic variation were found $(\% P=$

Table 2. Allele frequencies for nine polymorphic loci in Sedum polytrichoides populations.

\begin{tabular}{|c|c|c|c|c|c|c|c|c|c|c|}
\hline \multirow[b]{2}{*}{ Locus/allele } & \multicolumn{10}{|c|}{ Population } \\
\hline & JWP-1 & JWP-2 & JG-1 & JG-2 & JG-3 & OG-1 & OG-2 & OG-3 & HO-1 & HO-3 \\
\hline$D i a-2^{\mathrm{a}}$ & 0.000 & 0.000 & 0.000 & 0.000 & 0.000 & 0.000 & 0.364 & 0.250 & 0.389 & 0.167 \\
\hline Dia- $2^{\mathrm{b}}$ & 0.750 & 0.808 & 0.982 & 1.000 & 0.833 & 0.940 & 0.500 & 0.750 & 0.611 & 0.833 \\
\hline Dia $-2^{\mathrm{c}}$ & 0.250 & 0.192 & 0.018 & 0.000 & 0.167 & 0.060 & 0.136 & 0.000 & 0.000 & 0.000 \\
\hline$F e^{\mathrm{a}}$ & 0.208 & 0.308 & 0.214 & 0.545 & 0.708 & 0.170 & 0.000 & 0.000 & 0.000 & 0.150 \\
\hline$F e^{\mathrm{b}}$ & 0.792 & 0.692 & 0.786 & 0.455 & 0.292 & 0.830 & 1.000 & 0.725 & 1.000 & 0.850 \\
\hline$F e^{\mathrm{c}}$ & 0.000 & 0.000 & 0.000 & 0.000 & 0.000 & 0.000 & 0.000 & 0.275 & 0.000 & 0.000 \\
\hline$I d h^{\mathrm{a}}$ & 1.000 & 1.000 & 0.482 & 0.591 & 0.583 & 0.080 & 0.091 & 0.025 & 0.111 & 0.000 \\
\hline$I d h^{\mathrm{b}}$ & 0.000 & 0.000 & 0.000 & 0.091 & 0.000 & 0.000 & 0.000 & 0.000 & 0.000 & 0.000 \\
\hline$I d h^{\mathrm{c}}$ & 0.000 & 0.000 & 0.393 & 0.318 & 0.417 & 0.920 & 0.886 & 0.975 & 0.889 & 1.000 \\
\hline$I d h^{\mathrm{d}}$ & 0.000 & 0.000 & 0.125 & 0.000 & 0.000 & 0.000 & 0.023 & 0.000 & 0.000 & 0.000 \\
\hline $\operatorname{Lap}-1^{\mathrm{a}}$ & 1.000 & 1.000 & 0.625 & 1.000 & 1.000 & 0.950 & 0.909 & 1.000 & 1.000 & 1.000 \\
\hline Lap- $I^{\mathrm{b}}$ & 0.000 & 0.000 & 0.375 & 0.000 & 0.000 & 0.050 & 0.091 & 0.000 & 0.000 & 0.000 \\
\hline Lap $-2^{\mathrm{a}}$ & 1.000 & 0.769 & 1.000 & 1.000 & 1.000 & 1.000 & 1.000 & 1.000 & 1.000 & 1.000 \\
\hline Lap $-2^{\mathrm{b}}$ & 0.000 & 0.231 & 0.000 & 0.000 & 0.000 & 0.000 & 0.000 & 0.000 & 0.000 & 0.000 \\
\hline $6 P g d^{a}$ & 1.000 & 1.000 & 0.714 & 0.909 & 0.917 & 0.910 & 0.795 & 1.000 & 0.622 & 0.700 \\
\hline $6 P g d^{b}$ & 0.000 & 0.000 & 0.286 & 0.091 & 0.083 & 0.090 & 0.205 & 0.000 & 0.289 & 0.300 \\
\hline $6 P g d^{\mathrm{c}}$ & 0.000 & 0.000 & 0.000 & 0.000 & 0.000 & 0.000 & 0.000 & 0.000 & 0.089 & 0.000 \\
\hline$P g m-2^{\mathrm{a}}$ & 0.917 & 1.000 & 0.732 & 1.000 & 0.958 & 0.890 & 0.841 & 1.000 & 1.000 & 1.000 \\
\hline$P g m-2^{\mathrm{b}}$ & 0.083 & 0.000 & 0.268 & 0.000 & 0.042 & 0.060 & 0.045 & 0.000 & 0.000 & 0.000 \\
\hline $\operatorname{Pgm}-2^{\mathrm{c}}$ & 0.000 & 0.000 & 0.000 & 0.000 & 0.000 & 0.050 & 0.114 & 0.000 & 0.000 & 0.000 \\
\hline$T p i-I^{\mathrm{a}}$ & 0.875 & 1.000 & 1.000 & 0.955 & 1.000 & 1.000 & 1.000 & 1.000 & 0.911 & 1.000 \\
\hline$T p i-I^{\mathrm{b}}$ & 0.125 & 0.000 & 0.000 & 0.045 & 0.000 & 0.000 & 0.000 & 0.000 & 0.089 & 0.000 \\
\hline$T p i-2^{\mathrm{a}}$ & 0.958 & 1.000 & 1.000 & 1.000 & 1.000 & 1.000 & 1.000 & 1.000 & 0.956 & 1.000 \\
\hline$T p i-2^{\mathrm{b}}$ & 0.042 & 0.000 & 0.000 & 0.000 & 0.000 & 0.000 & 0.000 & 0.000 & 0.044 & 0.000 \\
\hline
\end{tabular}


37.5, $A R=1.40, A=1.43$, and $H_{\mathrm{e}}=0.112$ ) (Table 1). When the samples were pooled, we found higher levels of genetic variation owing to among-population genetic component (Table 1). We did not find significant indication of recent bottlenecks in all population of $S$. polytrichoides (data not shown).

\section{Inbreeding and population genetic structure}

Except for OGP-2, population-level $F_{\text {IS }}$ estimates in the remaining nine populations were significantly positive at the 0.05 level (Table 1). These results, as well as the significant multi-population-level $F_{\text {IS }}\left(F_{\text {IS }}=0.331, \mathrm{p}=0.001\right)$ (Table 1), indicated a substantial deficit of heterozygotes within populations of $S$. polytrichoides.

Deviations from $\mathrm{H}-\mathrm{W}$ expectations due to allele frequency differences between populations were significant and moderate $\left(F_{\mathrm{ST}}=0.250, \mathrm{p}=0.001\right)$. The results of AMOVA revealed that variation among the four valleys was larger than that found among populations within individual valleys (19\% vs. 9\%) (Table 3). A higher between region (i.e., northern valleys vs. southern valleys) component was found compared to among populations within regions ( $24 \%$ vs. $11 \%$ ) (Table 3$)$. A putative stronger barrier was found between the two northern valleys
$(10 \%)$, whereas there was a very weak barrier between the two southern valleys $(2 \%)$ (Table 3$)$.

We inferred two gene pools $(K)$ both by the "plateau" (Pritchard et al., 2010; results not shown) and the Evanno et al. (2005) methods (Fig. 2A): most individuals from northern valleys belonged to one cluster whereas most individuals from the southern valleys belonged to the alternative cluster (Fig. $2 \mathrm{~B}$ ), and such pattern of distinctiveness between northern and southern valleys was maintained at higher $K$ values (data not shown).

We found a significant correlation between pairwise genetic differentiation estimates and their corresponding logarithm of pairwise geographic distances $(r=0.767, p=0.001)$ (Fig. 3), suggesting that populations are at regional equilibrium of gene flow and drift across JNP and its vicinity.

\section{Discussion}

\section{Genetic diversity and inbreeding}

Levels of within-population genetic diversity of $S$. polytrichoides are slightly lower compared to $S$. kamtschaticum and H. ussuriense (Table 1). These levels of genetic diversity

Table 3. Hierarchical analysis of molecular variance (AMOVA) for Sedum polytrichoides.

\begin{tabular}{|c|c|c|c|c|c|c|c|}
\hline Source & $\mathrm{df}$ & SS & MS & Var.comp. & & Percent variation & \\
\hline & \multicolumn{4}{|c|}{ Sedum polytrichoides } & S. polytrichoides & S. kamtschaticum & H. ussuriense \\
\hline Among four valleys & 3 & 76.138 & 25.379 & 0.178 & 19 & 4 & 19 \\
\hline Among populations within valleys & 6 & 26.375 & 4.396 & 0.083 & 9 & 13 & 10 \\
\hline Within populations & 476 & 316.487 & 0.665 & 0.665 & 72 & 83 & 71 \\
\hline Total & 485 & 419.000 & - & 0.927 & 100 & 100 & 100 \\
\hline Between regions & 1 & 57.009 & 57.009 & 0.245 & 24 & 9 & 24 \\
\hline Among populations within regions & 8 & 45.504 & 5.688 & 0.107 & 11 & 11 & 10 \\
\hline Within populations & 476 & 316.487 & 0.665 & 0.665 & 65 & 80 & 65 \\
\hline Total & 485 & 419.000 & - & 1.017 & 100 & 100 & 100 \\
\hline Between northern valleys & 1 & 11.662 & 11.662 & 0.107 & 10 & 0 & 1 \\
\hline Among populations within valleys & 3 & 12.856 & 4.285 & 0.110 & 10 & 20 & 14 \\
\hline Within populations & 147 & 121.844 & 1.678 & 0.839 & 80 & 80 & 85 \\
\hline Total & 151 & 146.362 & - & 1.056 & 100 & 100 & 100 \\
\hline Between southern valleys & 1 & 7.467 & 7.467 & 0.012 & 2 & 0 & 3 \\
\hline Among populations within valleys & 3 & 13.519 & 4.506 & 0.064 & 9 & 8 & 10 \\
\hline Within populations & 329 & 194.643 & 0.592 & 0.592 & 89 & 92 & 87 \\
\hline Total & 333 & 215.629 & - & 0.668 & 100 & 100 & 100 \\
\hline
\end{tabular}

Note that "between regions" means between northern (Juwang and Jeolgol) valleys and southern (Okgye and Haok) valleys. Data (percent variation) for S. kamtschaticum and Hylotelephium ussuriense were from Chung et al. (2014b).

df, degrees of freedom; SS, sum of squares; MS, mean squares; Var. comp., variance component; percent variation, percentage of total variance contributed by each component. 
A

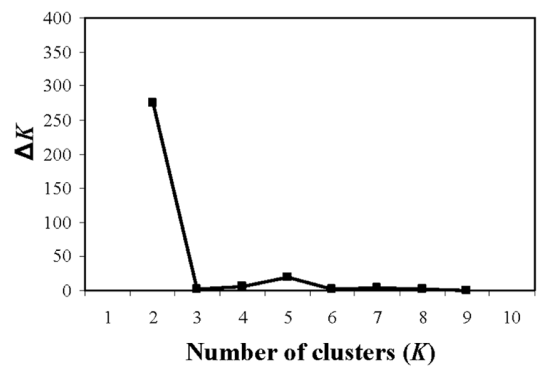

B

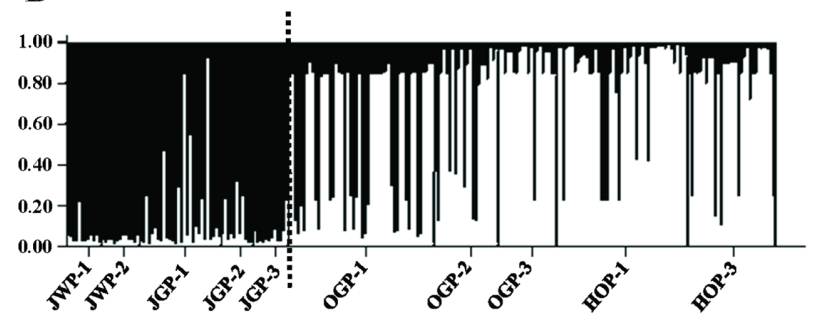

Fig. 2. Results of STRUCTURE for all Sedum polytrichoides individuals examined. A. The most likely $K$ is estimated using the $\Delta K$ statistic of Evanno et al. (2005). B. Assignation of individuals to the genetic clusters at $K=2$. Left to the dotted line, populations from northern valleys (Juwang and Jeolgol valleys); right to the dotted one, populations from southern valleys (Okgye and Haok valleys).

are, however, still higher than the reference values for populations of short-lived herbaceous perennials (means $\% P=$ 28.0, $A=1.40, H_{\mathrm{e}}=0.096$ ) (Hamrick and Godt, 1990) and plant species with mixed-animal breeding system (means $\% P=29.2$, $A=1.43, H_{\mathrm{e}}=0.090$ ) (Hamrick and Godt, 1990). However, although the review by Hamrick and Godt (1990) has been often cited for species comparison, we have to note that only $28 \%$ of the variation for levels of genetic diversity at the population level is explained by life-history traits.

Moderate levels of genetic variation in S. polytrichoides are compatible with an scenario of demographical stability, as this decreases the likelihood of loss of genetic variation through drift (Barrett and Kohn, 1991; Charlesworth et al., 2003). The results of BOTTLENECK indicate the absence of genetic bottlenecks within approximately the past $2 N_{\mathrm{e}}-4 N_{\mathrm{e}}$ generations ( $N_{\mathrm{e}}$, effective population size) (Piry et al., 1999), suggesting that size of populations has been somewhat stable in JNP and its vicinity in recent times. Populations of $S$. polytrichoides would have maintained relatively large sizes even during the LGM, given that the Baekdudaegan and some of its branches, such as the Nakdongjeongmaek (where the study area is located) (Fig. 1), have been suggested to harbor large refugial areas on the basis of both genetic and paleoecological data; Chung et al. (2017) reported a common pattern of high/

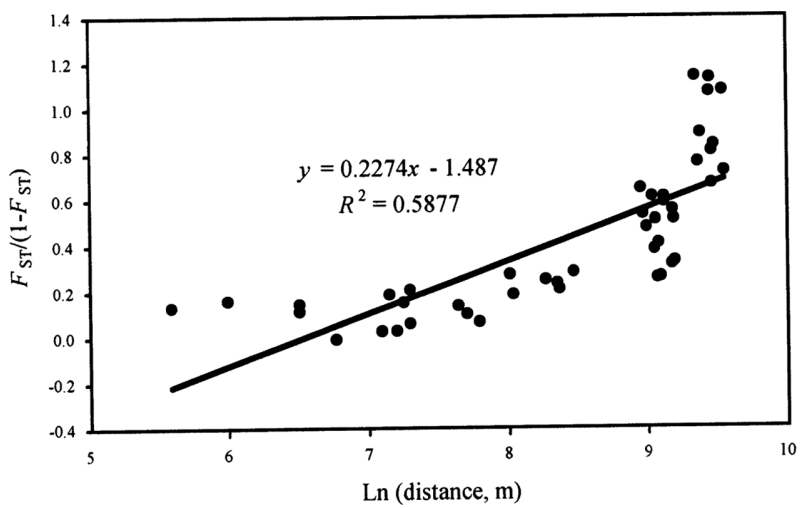

Fig. 3. Differentiation between populations of Sedum polytrichoides. Multilocus estimates of pairwise differentiation of $F_{\mathrm{ST}} /\left(1-F_{\mathrm{ST}}\right)$ are plotted against logarithm (Ln) of pairwise geographic distances in kilometers according to Rousset (1997). There was a significant positive relationship between pairwise $F_{\mathrm{ST}} /$ $\left(1-F_{\mathrm{ST}}\right)$ and $\mathrm{Ln}$ of pairwise geographic distance $(\mathrm{r}=0.767, \mathrm{p}=$ $0.001)$.

moderate within-population genetic diversity for species native to the Baekdudaegan $\left(H_{\mathrm{e}}=0.159, \mathrm{n}=16\right)$. Estimates of genetic diversity for the three stonecrops studied including $S$. polytrichoides are close to these values. In addition, the populations of all assessed plant species that occur within the study area harbor moderate to high levels of genetic variation within populations (with the single exception of Berchemia berchemiifolia) (Chang et al., 2003): Lilium cernuum $\left(H_{\mathrm{e}}=0.161\right)$ (Chung et al., 2014a), and the congeneric Iris odaesanensis and $I$. rossii $\left(H_{\mathrm{e}}=0.120\right.$ and $H_{\mathrm{e}}=0.132$, respectively) (Chung et al., 2015).

The significant deficit of heterozygotes within populations of $S$. polytrichoides, S. kamtschaticum, and $H$. ussuriense (multi-population $F_{\text {IS }}=0.331,0.272$, and 0.246 , respectively) (Table 1) is likely caused by non-random mating among relatives. If the three species are self-incompatible (we believe so because Crassulaceae are usually self-incompatible) (Thiede and Eggli, 2007), biparental inbreeding (that is generated by limited pollen and/or seed dispersal) and a Wahlund effect may account for this deficit of heterozygotes.

\section{Effect of physical barriers on genetic differentiation}

As predicted, the degree of genetic differentiation among populations of $S$. polytrichoides is moderate $\left(F_{\mathrm{ST}}=0.250\right)$ and fall within the range of the other Sedum/Hylotelephium species that co-occur in the study area (0.261 in H. ussuriense and 0.165 in S. kamtschaticum) (Chung et al., 2014b). These values are somewhat higher than those reported for short-lived herbaceous perennials (Nei's $G_{\mathrm{ST}}=0.233$ ) (Hamrick and Godt, 
$1990)$ and species with mixed-animal breeding system $\left(G_{\mathrm{ST}}=\right.$ 0.216) (Hamrick and Godt, 1990). Compared to these, our estimates are surprisingly high, given the close distances between populations of the three species in the study area (range ca. 0.13-14.27 km). Again, however, we have to note that the review by Hamrick and Godt (1990) demonstrated that about $47 \%$ of the variation in $G_{\mathrm{ST}}$ values among populations is explained by life-history traits.

Results from STRUCTURE analysis for S. polytrichoides exhibit the existence of two roughly differentiated clusters: populations from the northern valleys (Juwang and Jeolgol valleys) on the one hand and those from the southern valleys (Okgye and Haok valleys) on the other hand (Fig. 2B). The same pattern (northern valleys vs. southern valleys) of genetic clustering was also found for H. ussuriense (Fig. 3 in Chung et al., 2014b) but not for S. kamtschaticum, for which genetic segregation of northern vs. southern valleys is much less apparent (Fig. 3 in Chung et al., 2014b). Similarly to STRUCTURE, AMOVA shows a much higher between-region (i.e., northern valleys vs. southern valleys) component in $S$. polytrichoides and $H$. ussuriense (24\% each) relative to $S$. kamtschaticum (9\%; Table 3). This genetic divide is also evident from the distribution of exclusive alleles: $I d h^{b}$ and Lap$2^{b}$ for the northern valleys and Dia-2 $2^{a}, \mathrm{Fe}^{c}, 6 P g d^{k}$, and Pgm$2^{c}$ for the southern valleys in S. polytrichoides (Table 2); Dia$2^{b}, \mathrm{Dia}^{c} 2^{c}, \mathrm{Fe}^{a}, \mathrm{Fe}^{d}, \mathrm{Me}^{c}, 6 P g d^{b}, P g m-1^{b}$, and $P g m-2^{a}$ for the northern valleys in $H$. ussuriense (Appendix S1 in Chung et al., 2014b). Notably, some of these private alleles occurred at high frequencies, which are indicative of low gene flow rates (Slatkin, 1985). In contrast, only three alleles were exclusive for the northern valleys in S. kamtschaticum $\left(\mathrm{Me}^{a}, \mathrm{Pgm}_{\mathrm{2}} \mathrm{C}^{d}\right.$, and $\left.T p i-2^{b}\right)$ which, in addition, occurred at very low frequencies (well below 0.100) (Appendix S2 in Chung et al., 2014b). Thus, a strong barrier for gene flow can be hypothesized between Jeolgol and Okgye valleys - which are separated by ca. $8 \mathrm{~km}$ for two of the species (H. ussuriense and S. polytrichoides). This stretch comprises some relatively high mountains (including Mujangsan and Byeolwabi peaks, of over $600 \mathrm{~m}$ a.s.l.) (Fig. 1), and multiple ravines and valleys, delineating a highly dissected terrain. The total lack of intervening populations for $H$. ussuriense (and almost total for $S$. polytrichoides) would have made these $8 \mathrm{~km}$ insurmountable for the natural dispersal of the two stonecrops, whereas the more or less continuous occurrence of S. kamtschaticum would have ensured a high degree of genetic cohesion.

The AMOVA reveals that barriers for gene flow, in contrast, seem not to be very strong between the two northern (i.e., Juwang and Jeolgol) valleys (except for S. polytrichoides, with a percent variation of up to $10 \%$ ) and also between the two southern (Okgye and Haok) valleys (Table 3). The lack of apparent barriers for gene flow between Okgye and Haok valleys for the three species is an expected result as the populations are relatively continuously distributed along two converging streams (Fig. 1); indeed, and according to $\mathrm{Ku}$ et al. (2011), populations of H. ussuriense would have once constituted a single, continuous population that was fragmented as a result of human activities (mainly road construction). The two northern valleys are separated by less than $4 \mathrm{~km}$, a physical but not a genetic barrier for all the species with the relative exception of S. polytrichoides. Why S. polytrichoides, even having a few intervening populations, show larger genetic differentiation between the two northern valleys than $H$. ussuriense is an intriguing question that could be related to differences in historical gene flow between the two species (e.g., occurrence of fewer in between populations in the northern valleys in the past compared to the present).

In sum, we chose three species (nearly congeneric) in JNP and its vicinity which have different distribution patterns (higher abundance and more continuous distribution in $S$. kamtschaticum relative to $S$. polytrichoides and H. ussuriense). We showed that there was a difference in the genetic structure among the three species based on the population genetic analyses using allozyme polymorphism, which seems to be primarily due to the differences in the distribution of the three species within the study area (rather than differences in pollination, seed dispersal mechanisms or some other unknown factors). More importantly, the present study demonstrates that relatively small-scale physical barriers to gene flow-even of only few $\mathrm{km}$ - have a considerable effect on genetic structure pattern of plant species.

\section{Acknowledgments}

The authors thank Beom Jin Shim and Myeong Soon Park for laboratory assistances and Ann C. Chung for checking the English on an earlier version of the manuscript. This research was supported by the Basic Science Research Program through the National Research Foundation of Korea (NRF) funded by the Ministry of Education (NRF-2013R1A1A2063524 and NRF-2013R1A1A3010892 to M.G.C. and M.Y.C., respectively).

\section{Literature Cited}

Barrett, S. C. H. and J. R. Kohn. 1991. Genetic and evolutionary consequences of small population size in plants: implications 
for conservation. In Genetics and Conservation of Rare Plants. Falk, D. A. and K. E. Holsinger (eds.), Oxford University Press, New York. Pp. 3-30.

Chang, C.-S., H. Kim and T.-Y. Park. 2003. Patterns of allozyme diversity in several selected rare species in Korea and implications for conservation. Biodiversity and Conservation 12: $529-544$.

Charlesworth, B., D. Charlesworth and N. H. Barton. 2003. The effects of genetic and geographic structure on neutral variation. Annual Review of Ecology, Evolution, and Systematics 34: 99-125.

Cheliak, W. M. and J. P. Pitel. 1984. Technique for starch gel electrophoresis of enzyme from forest tree species. Information report PI-X-42. Petawawa National Forestry Institute, Chalk River, Ontario, $49 \mathrm{pp}$.

Chung, M. Y., M. G. Chung, J. López-Pujol, M.-X. Ren, Z.-Y. Zhang and S. J. Park. 2014a. Were the main mountain ranges in the Korean Peninsula a glacial refugium for plants? Insights from the congeneric pair Lilium cernuum - Lilium amabile. Biochemical Systematics and Ecology 53: 36-45.

Chung, M. Y., J. López-Pujol and M. G. Chung. 2014b. Comparative genetic structure between Sedum ussuriense and $S$. kamtschaticum (Crassulaceae), two stonecrops co-occurring on rocky cliffs. American Journal of Botany 101: 946-956.

Chung, M. Y., J. D. Nason, J. López-Pujol, T. Yamashiro, B.-Y. Yang, Y.-B. Luo and M. G. Chung. 2014c. Genetic consequences of fragmentation on populations of the terrestrial orchid Cymbidium goeringii. Biological Conservation 170: 222-231.

Chung, M. Y., J. López-Pujol, Y. M. Lee, S. H. Oh and M. G. Chung. 2015. Clonal and genetic structure of Iris odaesanensis and Iris rossii (Iridaceae): insights of the Baekdudaegan Mountains as a glacial refugium for boreal and temperate plants. Plant Systematics and Evolution 301: 1397-1409.

Chung, M. Y., J. López-Pujol and M. G. Chung. 2017. The role of the Baekdudaegan (Korean Peninsula) as a major glacial refugium for plant species: A priority for conservation. Biological Conservation. http://dx.doi.org/10.1016/j.biocon.2016.11.040.

Clayton, J. W. and D. N. Tretiak. 1972. Amine-citrate buffers for $\mathrm{pH}$ control in starch gel electrophoresis. Journal of the Fisheries Research Board of Canada 29: 1169-1172.

Cornuet, J. M. and G. Luikart. 1996. Description and power analysis of two tests for detecting recent population bottlenecks from allele frequency data. Genetics 144: 2001-2014.

Earl, D. A. and B. M. VonHoldt. 2012. STRUCTURE HARVESTER: a website and program for visualizing STRUCTURE output and implementing the Evanno method. Conservation Genetics Resources 4: 359-361.
Evanno, G., S. Regnaut and J. Goudet. 2005. Detecting the number of clusters of individuals using the software STRUCTURE: a simulation study. Molecular Ecology 14: 2611-2620.

Fu, K. and H. Ohba. 2001. Crassulaceae. In Flora of China, Vol. 8. Brassicaceae through Saxifragaceae. Wu, Z.-Y. and P. H. Raven (eds.), Science Press, Beijing and Missouri Botanical Garden Press, St. Louis, MO. Pp. 202-268.

Godt, M. J. W. and J. L. Hamrick. 2001. Genetic diversity in rare southeastern plants. Natural Areas Journal 21: 61-70.

Goudet, J. 1995. FSTAT (version 1.2): a computer program to calculate F-statistics. Journal of Heredity 86: 485-486.

Hamilton, J. A. and C. G. Eckert. 2007. Population genetic consequences of geographic disjunction: a prairie plant isolated on Great Lakes alvars. Molecular Ecology 16: 1649-1660.

Hamrick, J. L. and M. J. W. Godt. 1990. Allozyme diversity in plant species. In Plant Population Genetics, Breeding and Genetic Resources. Brown, A. H. D., M. T. Clegg, A. L. Kahler and B. S Weir (eds.), Sinauer Associates, Sunderland, MA. Pp. 43-63.

Hardy, O. J. and X. Vekemans. 2002. SPAGeDi: a versatile computer program to analyse spatial genetic structure at the individual or population levels. Molecular Ecology Notes 2: 618620.

Haufler, C. H. 1985. Enzyme variability and modes of evolution in Bommeria (Pteridaceae). Systematic Botany 10: 92-104.

Hwang, S. K., B. J. Lee and A. J. Reedman. 2007. Flow lineations and emplacement processes of the Juwangsan tuff, eastern Cheongsong, Korea. Journal of the Geological Society of Korea 43: 463-476. (in Korean)

Karron, J. D. 1987. A comparison of levels of genetic polymorphism and self-compatibility in geographically restricted and widespread plant congeners. Evolutionary Ecology 1: 47-58.

Karron, J. D. 1991. Patterns of genetic variation and breeding systems in rare plant species. In Genetics and Conservation of Rare Plants. Falk, D. A. and K. E. Holsinger (eds.), Oxford University Press, New York. Pp. 87-98.

Ku, Y.-B., H. K. Oh, Y. J. Chun and K.-H. Cho. 2011. High genetic differentiation in endangered Sedum ussuriense and implications for its conservation in Korea. Journal of Plant Biology 54: 262-268.

Landguth, E. L., S. A. Cushman, M. K. Schwartz, K. S. McKelvey, M. Murphy and G. Luikart. 2010. Quantifying the lag time to detect barriers in landscape genetics. Molecular Ecology 19: 4179-4191.

Le Corre, V., S. Dumolin-Lapègue and A. Kremer. 1997. Genetic variation at allozyme and RAPD loci in sessile oak Quercus petraea (Matt.) Liebl.: the role of history and geography. Molecular Ecology 6: 519-529. 
Mantel, N. 1967. The detection of disease clustering and a generalized regression approach. Cancer Research 27: 209-220.

Mitton, J. B., Y. B. Linhart, K. B. Sturgeon and J. L. Hamrick. 1979. Allozyme polymorphisms detected in mature needle tissue of ponderosa pine. Journal of Heredity 70: 86-89.

Nei, M. 1978. Estimation of average heterozygosity and genetic distance from a small number of individuals. Genetics 89 : 583-590.

Nei, M., T. Maruyama and R. Chakraborty. 1975. The bottleneck effect and genetic variability in populations. Evolution 29: 110.

Ohwi, J. 1965. Flora of Japan. Smithsonian Institute, Washington, D.C, 1066 pp.

Peakall, R. and P. E. Smouse. 2006. GenAlEx 6: genetic analysis in Excel. Population genetic software for teaching and research. Molecular Ecology Notes 6: 288-295.

Piry, S., G. Luikart and J.-M. Cornuet. 1999. Bottleneck: a computer program for detecting recent reductions in the effective population size using allele frequency data. Journal of Heredity 90: 502-503.

Pritchard, J. K., X. Wen and D. Falush. 2010. Documentation for Structure Software: Version 2.3. Department of Human Genetics, University of Chicago, Chicago. Retrieved Nov. 18, 2013, from http://pritch.bsd.uchicago.edu/structure_software/release _versions/v2.3.4/structure_doc.pdf.

Priya, S. 2007. Demography and native bee pollination of Sedum laxum (Crassulaceae), an endemic, clonal plant in a managed forest matrix landscape of the Siskiyou Mountains. Ph.D. dissertation, University of California, Santa Cruz, CA, 207 pp.

Rousset, F. 1997. Genetic differentiation and estimation of gene flow from $F$-statistics under isolation by distance. Genetics 145: 1219-1228.

Slatkin, M. 1985. Rare alleles as indicators of gene flow. Evolution 39: 53-65.
Slatkin, M. 1987. Gene flow and the geographic structure of natural populations. Science 236: 787-792.

Smith, J. M. 1999. Evolutionary Genetics. Oxford University Press, Oxford, 348 pp.

Soltis, D. E., C. H. Haufler, D. C. Darrow and G. J. Gastony. 1983. Starch gel electrophoresis of ferns: a compilation of grinding buffers, gel and electrode buffers, and staining schedules. American Fern Journal 73: 9-27.

Su, H., L.-J. Qu, K. He, Z. Zhang, J. Wang, Z. Chen and H. Gu. 2003. The Great Wall of China: a physical barrier to gene flow? Heredity 90: 212-219.

Thiede, J. and U. Eggli. 2007. Crassulaceae. In The Families and Genera of Vascular Plants, Vol. 9. Kubitzki, K. (ed.), Springer, Berlin. Pp. 83-118.

Weir, B. S. and C. C. Cockerham. 1984. Estimating $F$-statistics for the analysis of population structure. Evolution 38: 1358-1370.

Wright, S. 1965. The interpretation of population structure by $F$ statistics with special regard to systems of mating. Evolution 19: 395-420.

Wyatt, R. 1983. Reproductive biology of the granite outcrop endemic Sedum pusillum (Crassulaceae). Systematic Botany 8: 24-28.

Yamada, T. and M. Maki. 2012. Impact of geographical isolation on genetic differentiation in insular and mainland populations of Weigela coraeensis (Caprifoliaceae) on Honshu and the Izu Islands. Journal of Biogeography 39: 901-917.

Yeh, F. C., R. C. Yang and T. B. J. Boyle. 1999. POPGENE version 1.31-Microsoft Windows-based freeware for population genetic analysis. Quick Users' Guide. University of Alberta, Edmonton.

Zhang, Z.-Y., X.-M. Zheng and S. Ge. 2007. Population genetic structure of Vitex negundo (Verbenaceae) in Three-Gorge Area of the Yangtze River: the riverine barrier to seed dispersal in plants. Biochemical Systematics and Ecology 35: 506-516. 